\title{
Evolution of Organizational Forms in the Transition Period of Hungary ${ }^{*}$
}

\author{
Miklós Dobák / Ernõ Tari ${ }^{* *}$
}

A szerzök a cikkben - egy rövid történeti visszatekintés után - a magyar vállalati szervezeti formák fejlödését mutatják be 1980-as évektöl napjainkig. A magyar vállalati szervezeti formák jellemzői jól tükrözik az ország társadalmi, gazdasági változásait is. A szerzők bemutatják a 80-as évek (mint a "puha szocializmus" évei) útkereséseit a mikroszférában - külön kiemelve a kisvállalkozások fejlödésének a megindulását és jótékony hatását, illetve a nagyvállalati lineáris funkcionális szervezeti formák hegemóniájának a megszüntetésére tett kísérleteket. Ez utóbbiak közül külön is emlitésre méltóak a mátrix struktúrákkal történö próbálkozások, valamint a divizionális szervezetek kialakulásához elvezetö úgynevezett felelösségi és elszámolási egységek létrehozására tett kisérletek. A cikk második fejezetében a 80-as évek végén, illetve a rendszerváltozás kezdeti éveiben megfigyelhetö gazdasági és jogi szabá lyozás megtermékenyitö hatását mutatják be a szerzök, amelynek egyrészt a kisvállalkozások turbulens fejlödése, másrészt a mesterségesen kialakitott úgynevezett szocialista nagyvállalatok piackonform szervezeti struktúrába való átalakitása volt a következ ménye. A fejezet külön is foglalkozik a konszern-és holding szervezetek kialakulásáv al, amelyek mind a hagyományos nagyvállalatok lebontásának, mind a magyarországi magánvállalkozások növekedésének adnak mozgásformát.

Die Autoren stellen - nach einem kurzen geschichtlichen Rückblick - die Entwicklung der Organisationsformen ungarischer Unternehmen der achtziger und neunziger Jahre vor. Die Charakteristiken der Organisationsformen ungarischer Unternehmen spiegeln die gesellschaftlichen und wirtschaftlichen Veränderungen des Landes wieder. Die Autoren zeigen, wie während der achtziger Jahre, während des sogenannten 'weichen' Sozialismus, besonders die

Manuscript received: 23.4.95, revised: 10.5.95, accepted: 15.5.95.

** Miklós Dobák, born 1955, Professor, Chair of the Department of Management and Organization at the Budapest University of Economic Sciences, major areas of research interest: Organization Design, Management Control, Change Management.

Ernõ Tari, born 1941, Associate Professor, Department of Management and Organization at the Budapest University of Economic Sciences, major areas of research interest: Strategy, Strategic Alliances, International Management. 
Entwicklung und die positiven Wirkungen zahlreicher kleiner Unternehmen sowie das Schwinden der linear-funktionalen Organisationsformen bei zahlreichen Großunternehmen neue (Aus)wege für die Mikrosphäre wurden. Unter letzterem sind vor allem die Versuche mit Matrixstrukturen sowie die Schaffung von Verantwortungs- und Verrechnungseinheiten, Voraussetzung für eine Divisionsstruktur, zu nennen. Im zweiten Teil des Artikels beschreiben die Autoren, wie die wirtschaftlichen und rechtlichen Umgestaltungen während der achtziger Jahre und den ersten Jahren des Wechsels die turbulente Entwicklung der kleinen Unternehmen und die Umgestaltung der künstlich geschaffenen, sog. sozialistischen Großbetriebe in marktkonforme Organisationsstrukturen zur Folge hatten. Besonderes Interesse wird auch der Entstehung von Konzern- und Holdingorganisationen gewidmet. Diese geben neuen Spielraum für das Aufbrechen von traditionellen Großunternehmen und für das Wachsen von ungarischen Privatunternehmen.

\section{Preface}

Advances in Hungarian companies' organizational structures show a slightly different trend compared to experiences in most Central-Eastern European and ex-Soviet countries. The most important differences are felt in the development of Hungarian companies, which - unlike the Central - Eastern European standard - bear several elements (for instance establishing legally independent affiliates, or matrix and product management system, divisions) resembling corporate practice in the market economies as early as in the 80's (preceding the „big switch"). Reasons are found in relatively liberal and open economic policies (roots of which are traced back to 1968, the time of the „new economic mechanism" with the main objective to combine planned economy elements with those of market economies). On the other hand, in the 80's, there were political pressures advocating independent company management and decision making with an increasing urgency.

Thus we believe it is important to introduce the development of Hungarian companies' organizational structures in their historic context. The radical political changes in 1990 themselves would not provide sufficient explanation to understand the structural changes of Hungarian organizations.

One of the bases of our analysis was the research performed from the early 1970's until the mid 80's by the Faculty of Management and Organization at the Budapest University of Economic Sciences, concerning the study of the organizational and structural properties of the sixty biggest industrial enterprises. The study of these enterprises - which are responsible for about $50 \%$ of the Hungarian industrial production - was conducted by the colleagues of the Faculty, using mainly top management interviews and on site observation. 
We used information from several empirical sources for the description of organizational development of the enterprises after the mid 80's. We examined the internal documents of numerous enterprises and enterprise-groups, conducted personal interviews with executives, used company case studies and theses dealing with organizational analysis (prepared during the classes and specialized seminars under the guidance of our Faculty), and we also relied on the practical experiences gathered during the consultancy activity performed by the Faculty. Of the other sources, we analyzed professional articles, books dealing with certain aspects of the subject, and the informative articles of Figyelõ, Heti Világgazdaság and other Hungarian economic periodicals and daily papers.

In the study we differentiate among the examined organizational forms (structures) based on the following structural dimensions:

- specialization

- centralization - decentralization

- coordination

- configuration.

Under specialization, we mean the method of dividing a task-complex into subtasks and the installing of it to each of the organizational units (persons). Centralization - decentralization deals with the regulation of the competency (decision and direction sphere of authority) of the organizational units (persons) in the hierarchy. With coordination - in our understanding - the activity of the organizational units (persons) with different tasks and spheres of authority is harmonized, in order to achieve the organization's goals. Configuration refers to the span of control and the vertical hierarchical levels of the organization.

So the focuses of our study are the structural dimensions of the enterprises (companies) and the developmental characteristics of internal organizational independence; thus we do not deal with the analysis of operations, for example the production process. The examined organizations are within the state enterprise sphere, and its successor organizations joined by the self-supported domestic private capital organizations.

\section{Historical Background (1945-1980)}

The development of Hungarian organizational structures during 1945 to 1980 compared to organizational structural changes in the evolution of American or West European companies - is characterized by an epochal lagging behind by several decades. In order to explain the reasons for delay, the time period following the nationalization after 1945-1948 should be recalled when company structures were transformed according to the Soviet model. Essentially, the centralized functional organization representing the early first stage of Western company development served as the scheme to be followed. In consequence, by 
Western standards, out of date organizational formation - represented the initial point for organizing the new „socialist“ Hungarian enterprise. Later on, the centralized functional structures of organizations were preserved. What is more, these were strengthened by the enterprise mergers in the sixties (see Table 1). In those days the cooperation between newly formed large enterprises and developing, the integrated „cooperative“ relations of production units became established and gained ground. In the seventies, increase in the verticality of production of large Hungarian enterprises continues, even though their number was already disproportionate compared to small and medium enterprises. In the early eighties, centralized functional organization was still regarded as the almost exclusive organizational structure in Hungary (see Figure 1). This way, the Hungarian development of organizational forms between 1945 and 1980 has achieved the first stage of the US and Western European companies (which was completed by the fifties and sixties)! (Máriás et al. 1981)

Table 1: Comparison of Danish and Hungarian breakdown on enterprises size (\% of total enterprises)

\begin{tabular}{|c|c|c|c|c|}
\hline \begin{tabular}{|l|} 
Number of \\
Employees
\end{tabular} & Denmark & & & Hungary \\
\hline over 500 & & 1 & 37 & \\
\hline $200-499$ & & 4 & 25 & \\
\hline 100-199 & & 7 & 22 & \\
\hline 50-99 & & 12 & 12 & \\
\hline $20-49$ & & 29 & 3 & \\
\hline 5-19 & & 47 & 1 & \\
\hline
\end{tabular}


Figure 1: The organizational chart of a typical, linear-functional machinery large enterprise

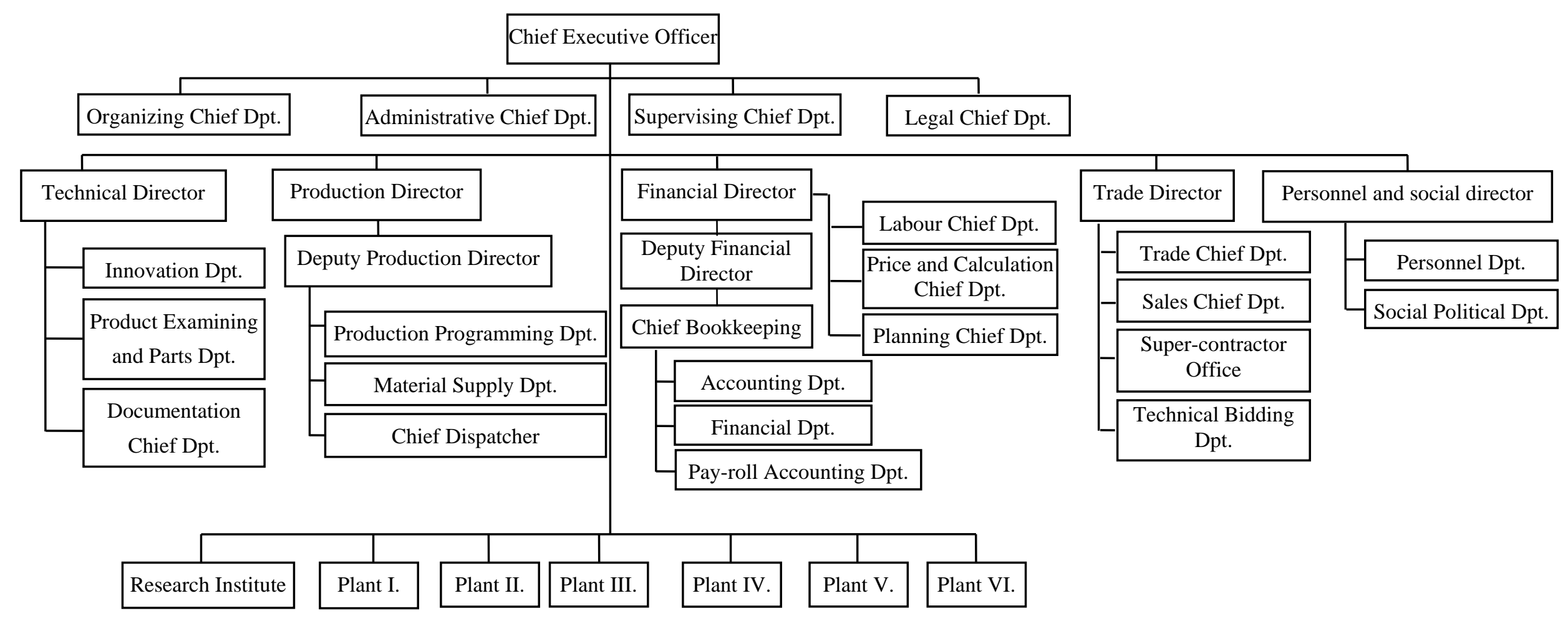




\section{Seeking Ways and Means in the 80's (1981-1987)}

By the early eighties, most of the external resources ensuring profitable corporate running or simply „surviving“ were used up or exhausted, and the partial actions made under the slogan of „structural modernization“ proved to be largely ineffective. It was clear that the exports expansion, particularly prompted by the central economic authorities and later on by gaining World Bank credits (the latter appearing as a new facility) could be achieved only by changes penetrating and renewing the organizational structure of state enterprises. Following this recognition, certain experts on innovation in the central and corporate economic management started to seek after opportunities for applying the organizational formations that had proved to be viable in developed industrial states. Seeking ways and means started in two directions. On one hand, experiments for (1) establishing new organizational formations essentially connected with small enterprises - were effected and, on the other, theoretical and practical steps for (2) changing organizational structures of conventional - centralized, linear-functional - large state enterprises were made.

\section{New Organizational and Legal Forms of Small Business}

It is worth pointing out the essentially more flexible, smaller organizations found in the frame of these new organizational formations. Such were, first of all, the so-called „economic working pools“, „small cooperatives“ and „civil legal partnerships“" operating independently from large organizations (while it has been allowed for some time to fund the „civil legal partnership“ in certain fields). It is considered that the biggest advantage of these organizations of private enterprise initiative is the motivation and interest of their management and personnel, which was generally much stronger than of those in conventional organizations. In the majority of cases this meant a higher requirement for performance. Drawing on the experience of small scale family enterprises in capitalist countries, it was found that signs of linear formations could be well perceived at these small enterprises. However, what is more significant was that the project type structural solutions could be found as a major part of these small organizations. Of course, this development was not deliberate in most cases, but resulted from the fact that there were small power distances in these organizations, without costly central apparatus, and the distribution of responsibilities among their employees could be amended flexibly, depending upon the current tasks. This provided for those working is small enterprises to have a qualification and mobility much higher than the national average.

The leaders of the Hungarian economy believed at this time that these small, private initiative organizations - besides filling the market gaps - would work their way into the national economic division of labour between companies. They 
were expected to be better connected to large enterprises through contractual relations and coordinated system of home-working. However, this remained mainly a mere wish, since, de facto, handling the small enterprises as „stepchildren“ was not eliminated even as late as the end of the 80's: No regulation providing equal conditions was introduced; the dominance of state property was maintained. And also, the organizational weakness of large state enterprises undermined the performance of these small enterprises, cutting back on their potential opportunities. (Makai 1991)

\section{First Organizational Modifications of Large State Enterprises}

\subsection{Efforts and Failures of Establishing Matrix Structure}

Initially, the intention to alter the organizational structures of the linearfunctional, conventional large state enterprises turned towards matrix organization and product management systems (introduced as a pioneer initiative in Hungary by the Taurus Rubber Works at the end of the 1970's).

The matrix structure for organizations seemed to be suitable for gaining ground and adopting competitive products more quickly, without having to break down the internal cooperation built up in large enterprises, or making major readjustments in decision-making authorities. Applying matrix management, the leaders of large enterprises - referring to the „impressed economy“ and the frequent amendment of regulations - could invariably maintain the connection between organization and environment in the old manner, through the corporate centre (headquarter).

Drawing on experiences up to now, the appearance of the matrix organization has represented some advances in mediating market effects and in establishing agreement between corporate functional areas and productive departments. At the same time, the principle of functional division of labour continued to be dominant in large enterprises implanting the matrix management, sometimes almost „putting down“ the product line. This was because in most cases the newly appointed product managers were not assigned with the right to give directions, but only with a reconciling and coordinating function provided by their formal role, or with the right to agree/disagree (see Figure 2 for a matrix structure based on a functional organization).

In the absence of balance between functional and product management, latent conflicts could not come to the surface and be „institutionalized“. The different interests could not confront to each other openly. Consequently, effective compromises or properly reconciled decisions for evolving the market sensibility, and regrouping resources rapidly and flexibly could not be made, either. In turn, the concentration on partial responsibility - so peculiar to the functional point of view - survived. The excessive written regulation remained 
in force, and as for functional bodies, they jealously watched over their resources, questioning from time to time the product management system as a whole.

The partial, or in some cases, total failure of Hungarian experiments aimed at introducing the matrix organization underlay the idea that the obsolete centralized functional organization was intended to transform directly into matrix type. In this way, the coordination was directed not to genuine independent units (e.g. divisions), but the organizational units - bedded in the conventional linear-functional hierarchy and left untouched in their authorities. These were drawn into the matrix network through the product managers. The consequence could not be other than the survival of the fundamental structure of the functional organization, since the functional (and line) managers could have an „effective hold“ on the product line from their previous position. This proved to be successful particularly when the product manager reported not directly to the enterprise's top manager but for example was posted under the direction of the head of a functional department. (Tari 1988)

Figure 2: The direction of functional based matrix organization in the early 80 's

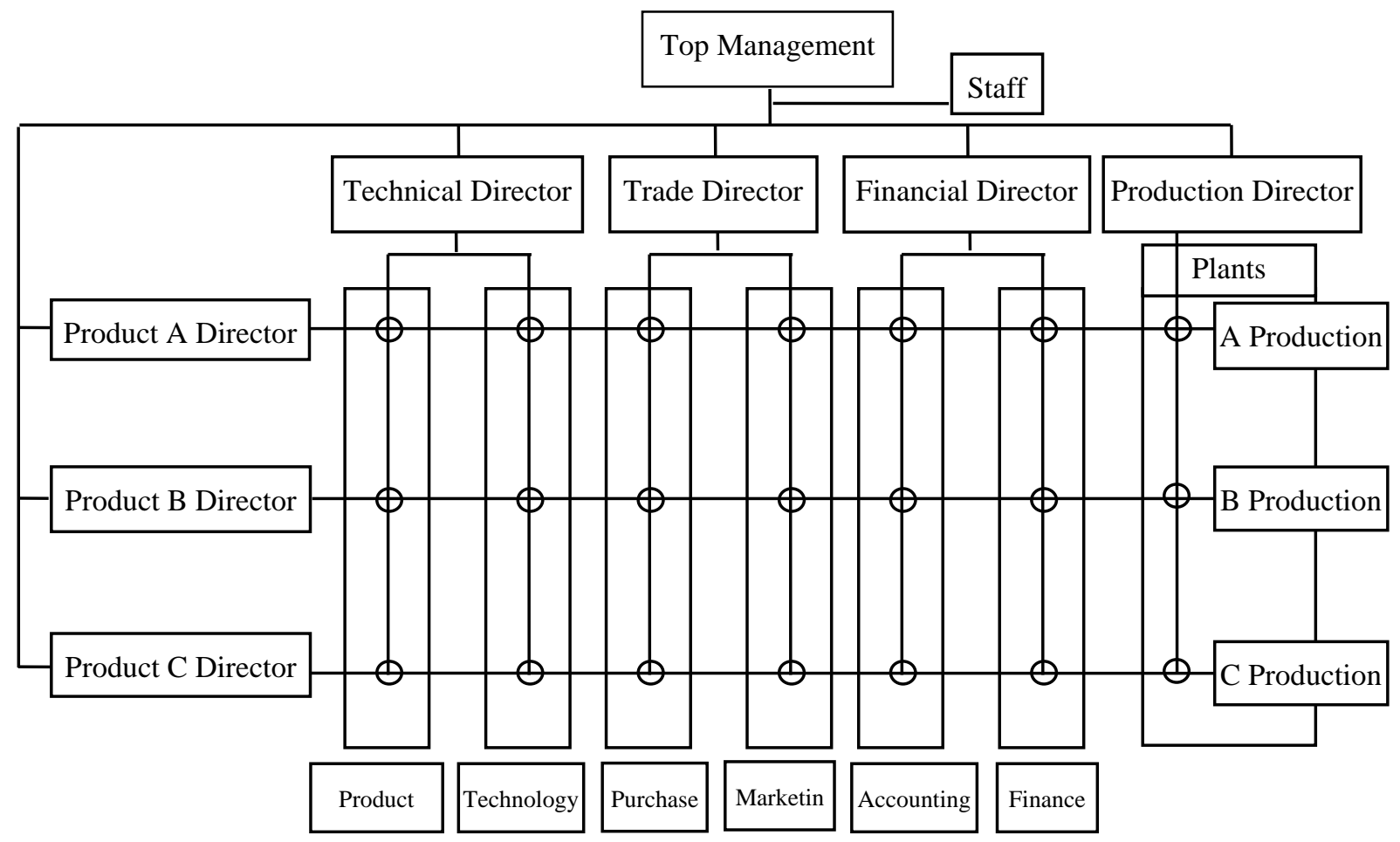

\subsection{Affiliates as Units of Responsibility and Accounting}

Affiliates - daughter company - as the internal company of the parent company, having a specific legal status, are considered to be an organizational formation applied and known in Western economies for a long time. These affiliates - 
assigned with considerable independence and a legal entity - have been operating as profit-oriented divisions (profit centers) in the organizational and proprietary frame of American and West European countries decades.

The appearance of the formation of affiliates in Hungary was connected to the organizational measures of partial central reforms initiated in 1981-1982. Nevertheless, executives of large enterprises have not regarded these affiliates as potential divisional profit centres. They took a view on the newly permitted organizational formation, rather as a „station“ leading towards the total independence of the plant division. This is why initially they listed numerous arguments against the establishing of affiliates of legal entity.

But later, they found the form of affiliates suitable for saving the important internal producing units, for upsetting the efforts to become totally independent, as well as for utilizing other financial and taxation benefits.

Among the large enterprises ,indisposed“ for shorter or longer periods, it was no secret that operation of the parent company is intended to be „straightened up“ by means of the affiliates. Large organizations battling against everyday financial troubles established affiliates from all (or almost all) the plant sections. Taking these considerations into account, it is not surprising that in many cases the elements of direction - reminiscent of the traditional relationship between the corporate centre and the plants - and the unilateral relations of dependence survived.

Therefore, to operate the affiliates as a unit of responsibility and accounting (for instance as a profit centre) was hindered by numerous limitations, provisions, and prohibitions by preemptory order on behalf of the parent enterprise. In contrast, it can be stated that affiliate formation - whilst breaking the privilege for ministries to found enterprise - triggered a sort of dynamic move in the field of independence. Numerous affiliates „became conscious“ in the meanwhile and learned to make use the authority they had obtained and increased freedom of movement. Conversely, other affiliates, could acquire only a formal set of rights and there was almost no difference in their position from the period of former „existence“: as a plant without legal entity. (Deák 1987)

\subsection{Ideas and Initial Steps for Developing the Divisional Organizations}

In the second half of the eighties, the projects for modernizing organization in order to increase their competitiveness and to adjust themselves flexibly were promoted by World Bank experts, American and West European consulting firms, and Hungarian organization designers. On the basis of their suggestions, the divisional formation of organization came to the fore gradually, offering good opportunities for creating genuine internal independence of large enterprises, for decentralizing responsibilities, and for developing the initiative of communities in plant divisions. 
Both favourable and unfavourable experiences were gained in the course of operating the divisions within the large companies whilst having no legal entity (self-accounting units, centres of responsibility, strategic business units, business branches etc.). At some large enterprises, the flexibility and the entrepreneurial spirit of internal divisions and plant units undoubtedly increased. In the possession of capacities put at their disposal, they were able to „switch over" to manufacture products requested by the market, within a relative short period of time. For certain enterprises, a venture project function under the direct supervision of head of division, was set up, endeavouring to exploit the opportunities disclosed by market survey' as soon as possible.

It is said, in general, that the division managers' proprietary view improved remarkably where these units learned to „think in money“.

Turning to the unfavourable phenomena, it should be pointed out that proposals for establishing divisions were not carried out to the full. Certain developments were in vain e.g. sales as a decentralized function by restructuring consultants, if the commercial apparatuses - left untouched in certain large enterprises continued to „coordinate“ the sales pursuit of divisions (profit centres). It occurred that Participation for a head of division in concluding the contracts concerning his own range of products or in discussions made with external partners, was not allowed. At another location, the division was allowed only to keep contact with the home market, while the enterprise centre continued to negotiate directly with foreign business partners.

Another basic principle of divisional organizations was violated when such requirements were imposed for plant unit divisions, the performance of which their managers could not influence in part or full. Similarly, the principle of divisional organizations was questioned by large enterprise centres which referring to the frequent regulatory amendments and the governmental „manual control“ developing between 1985 and 1988 - limited divisional manoeuvring by reallocating the resources and not even gave full scope for heads of profit (or cost) centres in distributing the resources within the division.

Generally speaking, it is said that the system of divisions not assigned with legal independence has left the centres of large enterprises untouched. (At a large chemical enterprise for instance, while functions were installed to newly organized divisions the central apparatus of several hundred, directed by seven Deputy General Manager invariably remained). In these large enterprises, said to be „divisional“, the cutting back of headquarters did not take place to an extent, that only coordination and strategic link functions were retained at the central management level. (Dobák 1988) 


\section{Economic and Legal Regulations Towards a Market Economy and Their Effects on Organizational Structure of State Enterprises and Private Firms (1988-1993)}

\section{Comprehensive Legal Regulations and the Conception of Privatization}

The period starting in 1988 is practically the overture for breaking down the centralized system of „socialist“ political and economic control. One of the most essential elements - having special importance on organizational structures - was the commencement of modification of economic and politic regulation. During these activities, elaboration of laws and legal rules has started which, through their codification in the period of 1988-1991:

- ensured the diversity of corporate or venture formations, the freedom of joining relieved the branch, sub-branch classification;

- altered the order of accounting and statistic provisions;

- allowed free venture for enterprises, and external and internal market movements;

- created the conditions for new labour and wages management as well as for restructuring the internal corporate systems of accounting and responsibility.

Legal regulations provided for diversity of company and venture formations. Freedom of joining - with regard to arrangement of organizational structures conform with market principles so that they offered a principal opportunity for establishing, terminating and permanently rearranging the company and partnership formations, developing in an organic manner, both in the small and large entrepreneurial spheres. The crucial law from this standpoint is, beyond doubt, the Act VI of 1988 on Business Organizations. This ensures the establishment and operation of company formations in Hungary, compare with organizations operating in the Western market economies. This law ensured, inter alia, secure frameworks for small enterprises and also offered possibilities for business done in trade-houses and for the creation of large organizations operating as a holding or concern.

Legislation of major importance was also launched in relation to changes to the accounting rules. This is because the former accounting system had - for its approach - a registration, accounting-oriented character. Supplying information speedily for preparing management decisions was difficult to achieve. Again, to create correct records on real expenses of cost-locations and cost-bearer was also difficult. It was difficult to achieve the separation of single units of accounting and responsibility, based on the obsolete accounting order, though all these are indispensable conditions for developing divisional organizations. The new accounting law came into force in 1991 (No. 1991/XVIII). 
To provide enterprise, it is essential that - for instance in case of realizing the divisional form of organizations - single divisions (especially if these are to operate like profit centres) will be in contact with the purchase and sales market. This also means that customers, suppliers, the home and foreign trade companies etc. should accept these divisions as partners having equal rights - independently from the legal status of the division.

Finally, it should be mentioned that the legislation provided independent labour and wages management for companies. One of the bases of sound operation of divisional organizations is the development of units of accounting and responsibility, as well as creating an internal system of interests serving the purposes of both the division and the company. It is therefore unavoidable for the company management to be independent in developing and operating systems of labour wages and management incentives. There is another reason for its importance, namely the wage differentiation within the company which may have an important - person-oriented - coordinating role. Wages and incomes can be effective means for the company management to select the heads of every single division and to „keep them in hand“ (just in order to effect the total company interests).

The new government formed after the free elections released its privatization concept in the autumn of 1990. The government program outlined three methods of privatization, i.e. when the ownership changes is initiated centrally, by the enterprise itself, and externally. The government intended a prime role for centrally initialized privatization from these methods and shortly afterwards, launched privatizing actions through the State Property Agency established in 1990. The so-called first privatization program concerned, in particular, large organizations operating divisions and self-accounting units without legal entity. (This is because state enterprises in a relatively favourable financial position seeming to be attractive for private investors - were found among the organizations). And for the smaller companies (maximum 300 persons) the government allowed the so-called self-privatization to start initiated by themselves. (Móra 1991)

At the end of 1992 the government elaborated, once again, a new privatization strategy and precisely stated the strengthening of a wide home proprietary circle. Practically the government desired to break with the former budget-income orientation of centrally initiated privatization, which lead to the slowing down of privatization actions due to centrally directed transactions and favourable deals of foreign capital investment. 


\section{Results of Comprehensive Legal Regulations on the appearance of Corporate Groups (Concerns and Holdings)}

\subsection{Preliminary Conceptual Remarks}

Concerns and holdings in developed industrial countries go back several decades. A company group jointly competing in an industry common market appearance, utilising development resources, optimum capital allocation as well as coordinated product and technology policy, is referred to as a concern. Accordingly, a concern is the form of appearance of capital concentration in which solutions are both built upon lateral or horizontal principles and those preferring vertical connections. That is, there are structures in which contracts or other horizontal type system of relations control the common uniform appearance, and there are concerns (characteristics in practice) in which a sub/superordinate relationship is developed between the enterprises. This is why managing and managed companies and business units are mentioned. (Theissen 1992)

The expression of holding, both in ist theoretical and practical guise in Hungary is mixed with the concern concept very often. The relationship between a holding and a concern is not expressly made clear in the special literature or in practice.

Recently, perspectives were clarified up, or got nearer to each other, and there is a compromise shown in the following interpretation: the holding is partly a special case of the concern where the managing company as a holding, influences the managed company, basically with the means of „property handling“ alone. This means that the managing company (holding) intervenes into the life of the managed business organization through the forums which are deemed suitable be the different corporate rights (General Assembly, Owners' Meeting) and making it possible to enforce the effect of external assessment (e.g. purchasing of shares through share sale). The holding, at the same time, can not be considered simply as a special case, since the holding, in the case of an activity of mixed profile, can combine investments or capital property, between which the above mentioned relations do not exist in the case of a concern. (Hungenberg 1992)

Developing a concern or a holding has, of course set prerequisites both in building up a system of legal institutes and in proprietary structures.

Regarding this issue, studying the internal organizational and structural matters of the company is also very important, in connection with the „historic preliminaries" of Hungarian large enterprises.

The overall spread of concerns and holding organizations in the developed industrial countries is the result of an organic development. Formation of divisional organizations fostered this development to a great extent. There is a 
principle being established in classical divisional organizations, that units of accounting and responsibility exist, these render operative services related to a particular product group, to a particular region, and the role of the centre of divisional organization. These refer predominantly to dealing with strategic issues, to finance, investment and development issues, and to operating the coordinating mechanisms. The development of divisional structures has let the division operate in legally independent business organization formations, pursuing their activities more or less independently from each other whilst the managing centre organization has been transformed in the framework of the legal regulation into a managing company, according to proprietary structure.

To summarize, it can be stated that concerns and holdings show a structure solution similar in many regards to divisional organizations. Otherwise, this means that developing the concern and holding organization is unthinkable without operating a divisional type of structure. The market economies, and particularly the experiences gained in the developed industrial countries, serve to offer a number of lessons in relation to bringing about the domestic concern and holding structures.

One of the most important lessons in the course of studying the concern and holding structure in Western countries is that chronology, continuity and succession are effective from these structures. This means first of all that operative management conceptions and means of strategy finance and property handling indicate a specific order for organization transformation and organization development. This is especially to be considered for the Hungarian organization transformation, since the former structure of large state enterprises (including organization structures of trusts) might present the basis of a concern structure operating in a highly dictatorial way. In most cases, a concern coordinated through strategic or financial means can be the first station of the move from this base. It was hardly to be expected that transforming a large enterprise showing an operative concern structure of „zero status“ into a holding performing classical property handling tasks could happen in one step. However, it should be added that the types of concern management not imply automatically subsequent phases. The place taken by a certain concern in the national economy, its market determination, proprietary structure and technological peculiarities (with special attention to verticality) largely determine what type of philosophy of concern management can be realized. In this context, it is clearly shown that a concern having an intense verticality (e.g. in metallurgy) could never achieve, to all probability, a concern or holding structure operating with classical property handling functions. Otherwise formulated: this structure would be inadequate for the activity and technology run in this organization. In connection with concern and holding management in the developed industrial countries mixed solution are found very frequently. This means that in the course of managing a concern various types of concepts 
may coexist. The concern might have parts for which the centre exercises property handling functions of holding type, and in the case of the managed business organization, except for units closely belonging to the central concern core (core business), operative management can also take place. All these are inevitable, since the activities belonging to a concern or holding can be run in several markets or can be diverse and the organization can be operated through various technologies. (Bühner 1992)

For a significant portion of domestic efforts for organization transformation seeking after mixed solutions is unavoidable, as when transforming the organization of large companies it is reasonable to separate some pursuits closely belonging to the core business from those connected to the company primarily via capital functions. Ultimately there is the phenomenon of the socalled superposition related to concern and holding management. This is seen mainly at major multinational organizations where the operative, strategic, financial and property handling management are separated at superimposed organizational levels. This has the concrete meaning that holdings exercising a strategic and operative type management belong to a holding providing the financial and property handling function. With respect to the Hungarian enterprise and trust structures, this solution was expected to materialise only at the largest companies and trusts.

\subsection{Concerns and Holdings on the Basis of State Enterprises}

With the Act of Business Organizations (No 1988/VI) coming come into force, establishing legal forms of company by existing enterprises was accelerated. Up to March of 1990, more than 100 large organizations took a smaller or higher portion of enterprise assets into business units of legal entity (shareholder companies and limited liability companies).

Often those among Hungarian large enterprises, who had financial difficulties, found the organizational form of a corporate group appropriate and, according to this, started to operate former plants (producing units) and certain departments of the enterprise centre in the form of a shareholder company or a limited liability company. (Matolcsy 1991)

Simultaneously, the remaining part of enterprise centres, cut back in their functions and staff number, were transformed into so-called „state property handling centres“ or „managing companies“. In the course of the „metamorphosis“ into business units of legal entity, the majority of the restructured large enterprises substituted the strictly centralized, functional organization with the formation of a number of business units (shareholder companies and limited liabilities companies) directed by the property handler.

Beyond the enactment of Companies' Act of 1988, this spontaneous organizational metamorphosis could be accomplished within the meaning of the 
Act of Enterprise (1984). The latter law authorized organs of self-government of state enterprises (so-called enterprise committees) to decide about essential organizational changes. (Sárközy 1986).

In fact, organizational (and legal) transformations of large state enterprises into concerns and holdings were incorrectly referred to as „spontaneous privatization" by Hungarian public opinion, while at first no effective privatization was realized. (Voszka 1991a)

After the transformations, the same persons, who formerly sat in the top positions of large enterprises became the heads of the property handling centres. These „old-new“ top managers, controlling the majority of shares in the business units, declared and provided in advance at the transformation, and succeeded at least for a temporary period - in saving their influence and power, and the major part of their decision competence. In order to retain their position, they were willing to agree and to make a compromise with plant managers who required complete independence. This compromise took place peacefully for the most part, since finally, plants were satisfied with the independence from the higher level, promised by the legally separated business unit formation. Moreover, the willingness of plant managers to make a compromise was supported by the condition that directors, managers, deputy directors and some in other positions in a shareholder company or limited liability company - exempted from the limitations imposed by wage regulations - could reckon to have much higher income than the actual salaries belonging to posts in the former plant.

When applying the business unit formations as legal entities - contrary to preliminary assumptions - the independence of internal units at large companies did not increase automatically. Much depended upon what freedom plant sections had gained earlier. Where plant divisions dropped into the business unit formation with legal entities to form the state of "feudal“ defenselessness (almost overnight), the managing company - independently from possessing the majority of shares - gained a wider ground for realizing their intention to intervene. The property handling centre (holding) could prescribe for instance to its business units (companies) to contact with foreign business parties only indirectly, through the central trade division or to evaluate the common supplies between each other at old, internal accounting prices. Also, responding to old reflexes, the managing company (holding) could supervise the activity of their business units as well.

Nevertheless, the corporate group-model provided a relatively wider range to manoeuvre for the ex-plant divisions which were allowed, more or less, to decide on their own development, production and sales policy and to form their independent market and financial relations - in the frame of legal independence. With an increase in independence, modernizing the internal organization and management of the ex-plant division became possible, too. For instance, the role 
of the commercial sphere (including marketing) increased and production dominance was driven back. New functions (strategic planning, controlling) appeared at the level of new business units of legal entity, some Business units restructured their production sections into „mini“ divisions which did not do business, but were allowed to decide over the operative production management, the technical parameters of materials to be purchased, and to report on offers, orders, and to make proposals for prices to be developed. (Dobák et al. 1992)

Notwithstanding the positive movements, initially a good number of business units, managed with a deficit, operated within the corporate group. For business units of legal entity cancelling the East European exports and shrinking the domestic market was often accompanied by oppressive obligations of credit installment inherited from the past. (It is to be noted that in certain parts of corporate groups the plant departments transformed into business units could start with a „new page“, since the property handling centres assumed their debts.) However, the operational difficulties could be attributed not only to external reasons: among others, modernizing the product range, rationalizing the working procedures, providing adequate quality standards did not manage to work out everywhere. Just then, when establishing the companies, inventories were reevaluated to an artificially low level several times, and the cash assets „adjusted to this“, resulted in liquidity difficulties at an early stage. In addition, business units were charged by high rentals where the assets (real estates, machinery) remained in state property, because the cash percentage specified for the transformation in the Act of Business Organizations was not available for disposal. Last but not at least, a serious problem in operating business units of legal entities was raised by failing initially to change management. In the majority of cases the old directors of plant divisions became operative managers. This also occures in the new business units which, due to their former situation were usually proficient in managing the production but proved ill-suited for finding up new markets, for marketing tasks or financial management. (Voszka 1991b)

All in all, the formation of corporate groups made the first massive breakthrough in the centralized, functional organization of large state enterprises. This specific organizational/legal formation which appeared in the last period of the partystate regime, partially succeeded in clearing the air from tensions emanating from the differences of efficiency between the plants (factories) of large enterprises. (Otherwise, the possibility of total independence of plant divisions was ensured by a newly enacted law only as of 1990, offering a way of retirement for „separate internal economic units“ of large enterprises.) Similarly, the „closed“, hierarchical organization of large enterprises was partly „opened“ to new owners (banks, suppliers, clients) converting debts for shares. However, the appearance of new owners (beside the state) in the corporate groups did not mean privatization, because „external proprietors“ were from the circle of state 
owned banking institutions and state enterprises. (Foreign capital investment was not too significant at the time.)

\subsection{Transformations into Legal Forms of Company Without Establishing Concern or Holding Structure}

Critical remarks concerning „spontaneous privatisation“ or the process of transforming the large, state owned enterprises into organizational/legal form of company group grew considerably more frequent around 1989, during the first period of changing the political system. Critical voices stated among others that managing companies (property handling centres) were not subject to any formal control of performance and that right from the beginning „they get the owner's right for the shares or the founding capital as a free grant, and then as final proprietors they can do with the assets whatever they want“. (Auth/Krokos 1989)

However, spontaneous privatisation was not blocked officially by the government, although there had been some steps made to establish a „superholding“ to manage the assets of the state owned enterprises, despite protests by managers of large state owned firms.

The fact that the State Property Agency was founded in the spring of next year signalled that there was already some kind of consensus between certain political forces and different groups representing various economic interests which stated that ,an effective control over managing the state property is necessary“. (Szalay 1992)

This change in the official evaluation of spontaneous privatisation resulted in the fact that the corporate group model lost on popularity and a number of state owned enterprises were transformed into new entities as a whole. The transition law that was passed by parliament and that came into effect in mid-1989 provided the legal framework for this process. This concept means that firms keep their former organisational unity after the transformation into company form and can later be sold this way as well.

Very few companies transformed themselves according to this latter model before the formation of the State Property Agency, which showed that enterprise leaders preferred the spontaneous way of privatisation (concern-type organisational and legal structures) that had been enabled by the Act on business organisations which had been passed earlier.

Although spontaneous privatisation did actually occur on a much smaller scale, fewer and fewer managers decided not to apply the law of transition after 1990 . Spontaneous privatizations that took place after this were already controlled by the State Property Agency and it was limited to some factories of large organisations. 
There was suddenly a huge increase in the number of state enterprises starting to transform themselves as „one intact entity” (160 enterprises during the period between March 1990 and mid-1991). There are several factors explaining this phenomenon. No doubt, since the government had a different perspective to spontaneous privatization, politics must have played a role in the back of managers' mind. Firm leaders, eager to keep their positions and to avoid possible accusations thought twice before „organising the companies out of the social control" by deciding to apply the corporate group-model. Intending to keep the company organisation as one entity did also play an important role. Advantages of maintaining one single and intact company organization include aspects such as owning only one seat where the firm would have to continue working, or intensive co-operation in the production phase between different plants of the company (see Figure 3 as a printing firm transformed into a one level company form as a whole).

Managers also had to keep in mind the long term outlooks of the company as well as strategic interests: There was reason to believe that should the firm keep on working without any change in its organisational structure it would take no more than one or two years until serious problems would emerge, thanks to worsening economic conditions, the traditional markets getting scarcer, and the lack of resources to develop.

A further driving force was the fact that a new law was being prepared and later passed that forced nearly all state owned enterprises to transform into some new legal form of company by the middle of 1993. Consequently, it did not come as a surprise that the data base of the State Property Agency registered nearly 190 whole transformations during the year 1991, and 155 only during the first part of 1992.

\subsection{Development of Private Organisations After Act on Business Organisations Came Into Effect - From Small Business to Private Holding}

After the Act on Business Organizations came into effect, private initiative organizations adopting a direction of growth and transformed themselves wholly into legal forms of company (shareholder company or limited liability company). But the growth was not exclusively continuing in the framework of a single level company structure. 
Figure 3. Organization Chart of Petõfi Printing and Packaging Co. Limited by Shares (1994)

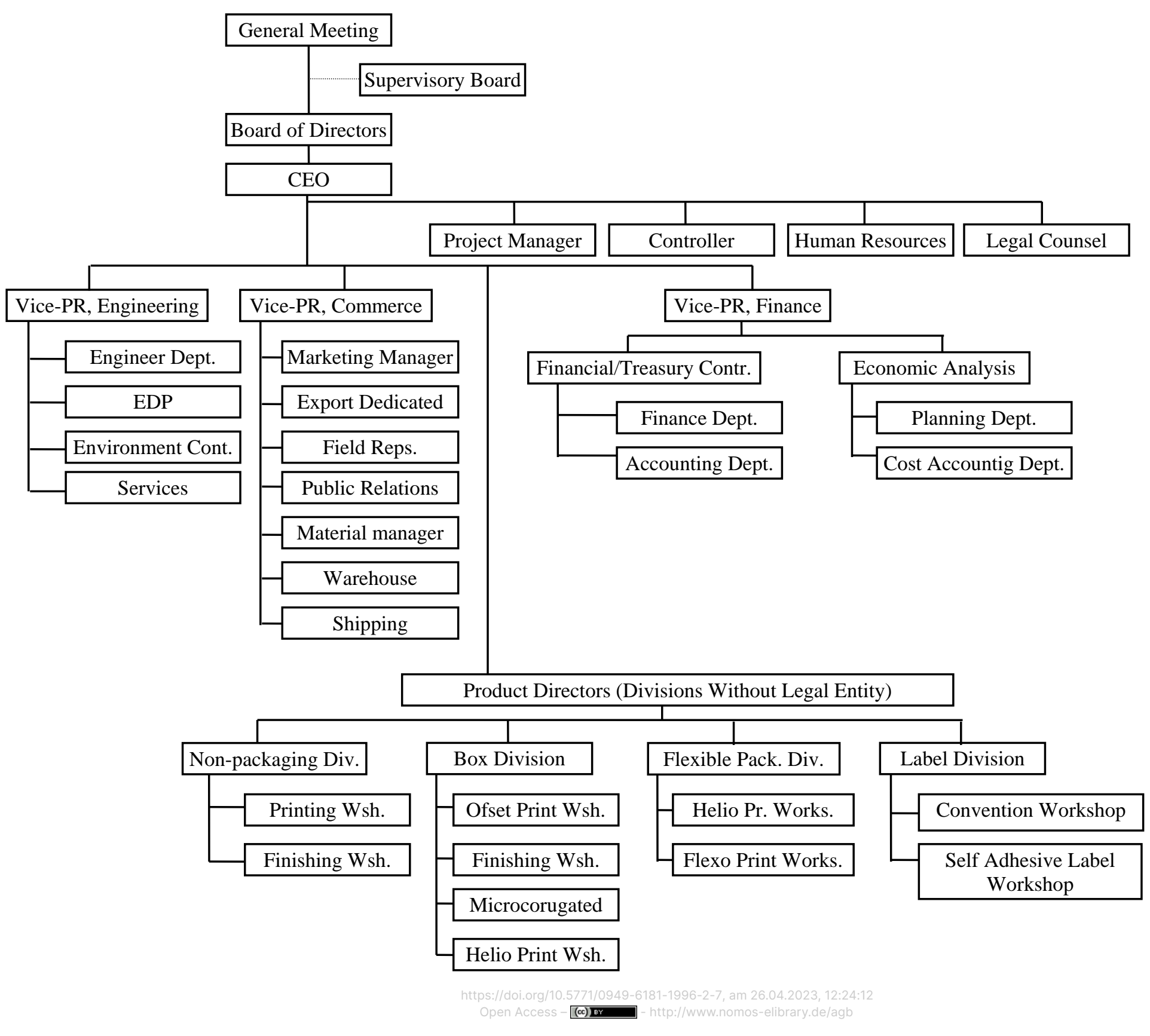


In reality, small „satellite“ firms were also founded, (with or without other, foreign or Hungarian investors) in parallel to the growth and transformation of the „mother entrepreneurship“. To be quite exact, this „quiet growth“ had started earlier: even before the Act on business organisations was passed small private initiative enterprises such as small co-operatives began to buy interests in a number of fields of activities. Some experts explain this by stating that it would have been a political risk to "grow too large“ in one field at all costs, particularly between 1986 and 1988, that is, before political changes started to happen. This might be the reason why private capital was divided among several small scale firms. (Meixner 1991)

This resulted in the fact that, on the turn of the decade, a number of expanding private initiative enterprises were transformed into limited or shareholders' companies while owning minority or majority shares parallel in several different firms. Business successes after the „flagship“ enterprise had been legally transformed then drove private entrepreneurs to found additional companies. Consequently, the transition from a single level company structure into a two level structure (holding) took place within a relatively short time with these dynamic private enterprises (one or two years altogether).

There was a ,, de facto “ and a ,, de jure " way to transform a private firm (with single company organization) into a holding. In the first case, the legal control of the group was not taken over by a holding centre, but the „flagship“ enterprise (or its leader) did have informal ways to control all functions of the group members. The second case meant that a holding structure was created officially as well, and all branches and divisions of the former one level company were transformed into separate legal entities, whereas the „rest“ that remained of the single company organisational structure took over the control functions of the holding centre.

The most frequent reason why growing private companies chose to apply a two level holding structure was that, due to the increase in market share and the number of employees, the activities of different divisions were about to get out of control. Also, shares owned in other companies could no longer be controlled without the supervision of a legally separated entity. Most private groups applied the methods of operative or strategic holding control, which means that control is not purely financial. This is quite similar to the case of the concerns emerging on the basis of state enterprises. (Fiáth/Kiss 1994)

There are two ways in which the private companies or groups of companies developed further. A part of them continued to invest too heavily - they built for example new headquarters - acquired shares in peripheral fields of activity, borrowed high-interest loans only to get into the trap of growth and then went bankrupt. (Varga 1993)

Another part of expanding private companies and company groups realised the dangers in growing too quickly and succeeded in slowing down and 
consolidating their spheres of activities. We will return to what happened afterwards with these two kinds of expanded private enterprises and holdings in the next section.

\section{Tendencies in the Development of Organisational Forms (Structures) in the Mid-Nineties}

\section{Successor Organisations of Large State Enterprises - the „Turn“ Events of Corporate Groups and of One Level Companies}

All that we can hope to describe when writing about the tendencies of organisational changes in the recent past is to broadly discuss the main directions and characteristics of these changes. In doing so, we will keep on following the previous structure of our analysis: on one hand we will shortly summarise recent experience of the successor organisations of state owned companies, whereas on the other hand we will also provide, (without claiming that we give an in-depth analysis) an overview of organisational issues of the Hungarian private sector with special regard to the difficulties that emerged during the last couple of years.

A. There are basically two directions in which formerly state owned companies, transformed into concerns (holdings) developed further. A part of them acted in a very responsible and conscious way and involved professional (meaning: not purely financial) foreign investors while selling them a share in the concern. These concerns (holdings) were capable of further building the corporate group and maintaining a large organisational structure (some of them by succeeding in persuading the state to write off debts of the concern) and these are currently either making a profit, or, at any rate, maintaining operations at an acceptable level. Concerns (holdings) in this category include Pannonplast Holding (plastic), Medicor (medical equipment), Dunaferr (steel) and Ganz Gépgyár Holding (machinery, see Figure 4). (S. Huszty 1995)

Another part of concerns based on state enterprises proved unable to maintain operating profitably, and have thus „fallen apart“. A part of these concerns (holdings) were either sold or went bankrupt, and large scale operations ceased to exist. Due to the fact that inland and East European markets had mostly been lost, some of these concerns could not be sold to investors any more so their assets were liquidated. (An example to this was Csavaripari Vállalat, once producing screws.) In case of other concerns (holdings), some companies of the corporate group were sold to private investors, the rest of the (inner) companies went bankrupt (or had to pass through a difficult period) and the property handling centre of the corporate group was liquidated. (See example of the shipyard Ganz Danubius). (Voszka 1994). In some other instances the company members of the corporate group split into smaller companies that are currently working independently, all by themselves (Magyar Optikai Mûvek). 
B. Our view is that if we have a look at companies that had been earlier transformed into a new legal entity as a whole there are also two main directions of development to be examined. A proportion of the companies that used to have a one level structure have transformed (or are about to transform) themselves and applied (or start to apply) a two level concern structure. The reason for that could either be to operate more effectively or to encourage investors to privatise the new inner companies. Another group of companies still stick to a one level structure. This can be the case where the privatisation strategy was successful and an „organic” structure could be developed. (A small portion of companies applied a die-hard strategy instead of privatisation and are constantly consuming their assets while heading for bankruptcy.)

Figure 4: The Organizational Structure of Ganz Holding as of January 1996.

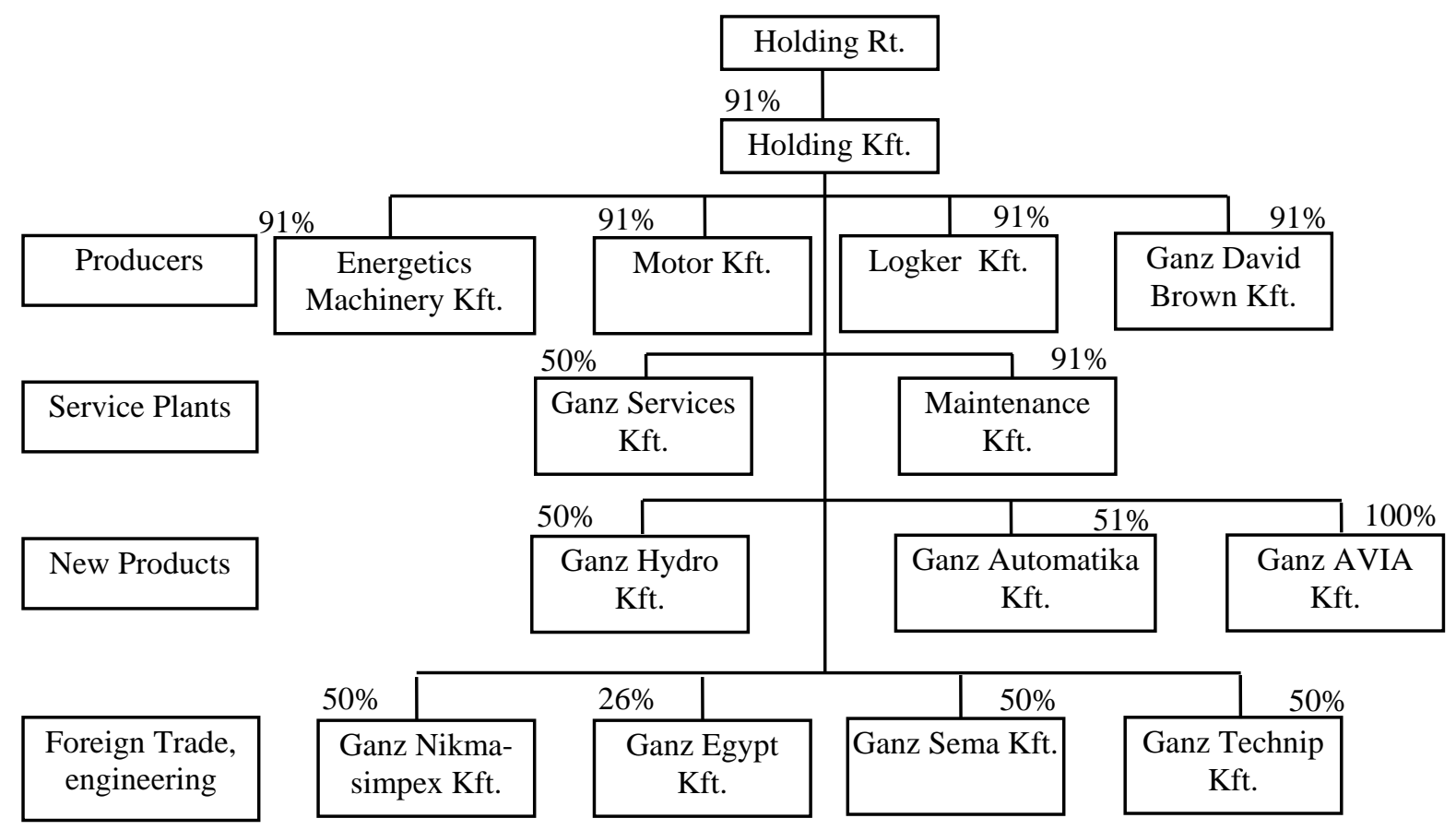

Rt.: a company limited by shares.

Kft.: a company of limited liabilities.

A company with a share of less than $100 \%$ is a joint venture (the number above the box represents the share of Ganz Holding in the company).

The most general reason why companies take further steps into the direction of a concern structure is that managers think the company group will be more ready to react to market challenges if the legal entities are smaller and have a clearer profile. Also, foreign capital is more likely to be invested in these smaller entities (inner companies). Two recent and typical examples for the transition of large shareholders' companies with one level organisational structures are Rába (a well known vehicle maker), and IBUSZ (a traditional travel agency). These organisations hope to combine the advantages of both large and small 
organisations within the concern structure (similarly to the intentions of the age of spontaneous privatisation). The experiences of the last one or two years seem to justify these expectations of effectiveness. (H. L. 1994)

Quite a few firms were able to find an investor (either professional or financial) among those companies that have kept the one level company structure all the time until now. (The privatisation strategy of these firms at the beginning was aimed at finding a professional investor to buy a minority stake, with an option to buy a majority share in the future, or to find a financial investor that would initially obtain a minority share which it would later sell to a foreign professional partner, thus enabling it to acquire a majority stake.) These companies developed a less rigid, „looser“ version of a linear-functional structure (as a result of the initiative of either the foreign partner or the Hungarian management). This inner structure seems to provide the necessary organisational and management framework for effective operations. Examples for this are, among others, Hungarian pharmaceutical companies (with an outstandingly high income/profit ratio of 20 to 25 per cent). It is worth noting here that these companies are mostly working at only „one seat“ where vertical connections between the phases of production do not force (or enable) the company to apply a divisional structure that would otherwise be considered to be „more advanced“. Examples for companies that have kept a one level structure and were successful in carrying out the kind of privatisation they had in mind include the two pharmaceutical „success stories“ Chinoin and Egis. (Tari 1994)

\section{Private holdings in the growth trap and the successful consolidations}

There were different things to happen to private groups after bankruptcy. Microsystem, once a computer seller „empire” simply ceased to exist after its shareholders decided to liquidate the company in November, 1994. The prestigious private firm could only maintain rapid growth by acquiring high interest loans, and although the capital assets were raised two years before the collapse, these extra resources were also used to finance a forced speed of growth. What is even worse, these resources were concentrated to markets where Microsystem had weak positions in the first place. After a lengthy period of considering what decision to make the proprietors explained: „we thought even if we had created a number of entirely independent, small limited companies they would only have produced profit for our creditors, and even afterwards it would have remained an open question whether Microsystem is ever to recover. The period of time after which recovery could be hoped for seemed to be too long." (Új Dunkerque 1994)

On the other hand, the case of Controll-group, another huge (but largely diversified) private holding represents another type of a company group after bankruptcy. The structure of Controll-group looked similar to what we described 
previously as a ,, de facto “ holding. This enabled the companies of the group to abandon Controll Rt., the holding centre. It is true that the flagship firm failed but smaller companies succeeded in buying themselves out and start a life of their own. Examples include Controll Quality Consulting and „head-hunter“ Hill International, as newly independent companies.

A manager of one of the former satellite firms explains: „This was possible thanks to the fact that Controll-group was not built up entirely based on profit reasons. Controll used to be a real incubator, where reasonable propositions of good experts could come to reality. Naturally, these firms were also in contact with the mother company, but not only and mainly with the mother company. This is why these firms are still alive today. " (Meixner 1993)

Private companies that were able to avoid falling into the growth trap realised the danger of growing too quickly as early as in 1991 or 1992. Firms where the management noticed the warning signs of increased debts started paying back a large part of them without hesitation: they sold entire branches, raised the assets, had their debtors pay the invoices, (even via court, if necessary). They introduced strict inventory control and made the organisation leaner. (In some cases this meant dismissing as much as several hundred people.)

A number of surviving private groups started to offer complex services instead of trading with goods in the traditional way. Others diversified operations, made it possible for separate branches to mutually support each other as well as integrating production and sales. The strategy aimed at finding market gaps „that had remained unseen before" which meant that operations could be built up from practically nothing, proved to be correct for selecting new markets: relatively huge sums of income could be collected relatively quickly.

Another major factor for success was when the system of incentives as well as the corporate group image, and management style were designed to fit the credo and strategy of the holding right from the very beginning, (both in the case of companies that were privately founded or bought). A number of holdings realised it was also necessary to renew the management and carry out personal changes. Since a period of growth is followed by a period of stabilisation, entrepreneur type top managers should be substituted by people who are capable of consolidate operations. Examples for companies sharing the opinions described above include Rolitron-group (medical equipment), Fotex-group (photo services, furniture production and retail, cosmetics, glassware, etc., see Table 2 on the growth of the Fotex-group) as well as Mûszertechnika Holding (computers, information technologies, and other kinds of technical equipment). (Dobák et al. 1996) 
Table 2: Members of the Fotex-group, the growth chronicle of four years

(In the brackets are the share capital and the share of Fotex Ltd.)

1989.

Fotex Ltd. /Limited Liability Company/ (236 million HUF)

Europtic Ltd. (234 million HUF, 50.1\%)

Multivízió Ltd. (1 million HUF, 50.1\%)

1990.

Fotex Ltd. /Shareholder company/ (September, 2601.6 million HUF, November 3101.6 million HUF)

Europtic Ltd. (234 million HUF, 50.1\%)

Multivízió Ltd. (71 million HUF, 50.1\%)

Proficolor Ltd. (1 million HUF, 30\%)

Ajka Kristály Ltd. (August 55.5 million HUF, 30\%; December 317 million, 50.1\%)

Azurunio Ltd. (254 million HUF, 93.0\%)

Azurinvest Ltd. (702 million HUF, 50\% of the voting shares)

Kontúr Ltd. (268 million HUF, 15\%)

1991.

Fotex Ltd. (4538.6 million HUF)

Multivízió Ltd. (73.5 million HUF, 53.6\%)

Europtic Ltd. (234 million HUF, 50.1\%)

Ajka Kristály Ltd. (March 705.5 million HUF, 50.1\%)

Azurunio Ltd. (254 million HUF, 93\%)

Azurinvest Ltd. (702 million HUF, 71.6\% of the voting shares)

Kontúr Ltd. (853 million HUF, 50.8\%)

Domus Ltd. (1633 million HUF, 6.1\%)

Fotex Agent Ltd. (1 million HUF, 51\%)

Interkristály Ltd. (48 million HUF, 50\%)

Ingatlanfejlesztõ Ltd. (1.3 million HUF, 90\%)

1992. Changes compared to previous year:

Fotex Ltd. (4606.6 million HUF)

Europtic Ltd. (234 million HUF, 100\%)

Ajka Kristály Ltd. (705.5 million HUF, 100\%)

Kontúr Ltd. (913 million HUF, 50.8\%)

Domus Ltd. (1633 million HUF, 21.1\%)

Ofotért Ltd. (1000 million HUF, 50\%)

Ingatlanfejlesztõ Ltd. (900 ,million HUF, 90\%)

G. Pharma Ltd. (1 million HUF, 100\%)

Számítástechnikai Ltd. (1 million HUF, 51\%)

\section{Conclusions, summary statements}

As it has been shown in the previous chapters, actual organisational changes have proven suppositions about small organisational structures becoming more frequent. Also, a large number of concerns and holdings have appeared, and the way they work did not come as a surprise to experts, either; breaking up of monolith state enterprises and organic growth of private initiative 
entrepreneurships provided the possibility for the functioning of concern and holding forms.

On the other hand, expectations concerning the creation and development of horizontal interorganizational cooperations, hire work, integration of activities, $\mathrm{R} \& \mathrm{D}$ cooperations and strategic alliances did not, or only partly proved to be successful.

The growing share of small private organisations directed professional interest to the importance of less formalised and regulated management structures and spontaneous inner mechanisms of managing an organisation.

Two level concern and holding structures made it possible for a certain section of the producing plants of large state owned enterprises to survive for a little while, „to take a deep breath“ while improving chances to convince outer capital to invest into the business unit. These production units were later developed into real divisions (profit centres) within the framework of the company group after a successful partial privatisation of the companies. Concern and holding structures could also be utilised to coordinate business units in private initiative companies as well as to create and encourage profit-orientation in separate branches of the private groups.

Viewing things from a different angle, it is also a fact that organisational networks (e.g. subcontracting) are not as wide-spread as could reasonably be expected, based on the large number of small organisations. The overwhelming majority of small enterprises have remained economically independent meaning that no long-lasting interorganizational cooperation links have been formed to the present time.

Similarly, due to a number of factors inherited from the past, there are still very few cooperations with a strategic vision in R \& D, marketing-sales, logisticspurchase between foreign and Hungarian (state owned or private) companies.

Nevertheless, some signs indicate that connections between companies are being reorganised. The disintegration of former interorganizational systems (as a result of market shocks, changes in the ownership and economic-political measures) seems to have come to an end. The volume of subcontractors' billings have increased considerably during the last two years, which means that the „trust crises“, the lack of confidence in one's partners is decreasing. There are three centres of gravity for subcontractors: successful industrial concerns based on former state enterprises, private company groups and subsidiaries of multinational companies established in Hungary.

The authors are grateful to Soma Horváth, Assistant to the Department of Management and

Organization for the finish up of the article. 


\section{References}

Auth, H. / Krokos, J. (1989): Kié az állami vállalat? Csodás átváltozások (Who is the owner of the state enterprise? Miraculous metamorphosis). Figyelõ. 9 February.

Bühner, R. (1992): Management - Holding. Verlag Moderne Industrie.

Deák, J. (1987): Vállalkozás és szervezeti formák (Entrepreneurship and organziational forms). Vezetés. Szervezés. March.

Dobák, M. (1988): Szervezetátalakítás és szervezeti formák (Organizational design and organizational forms). Közgazdasági és Jogi Könykiadó. Budapest.

Dobák, M. és munkatársai (1992): Szervezeti formák és koordináció (Organizational forms and coordination). Közgazdasági és Jogi Könyvkiadó. Budapest.

Dobák, M. és munkatársai (1996): Szervezeti formák és vezetés (Organizational forms and management). Közgazdasági és Jogi Könyvkiadó. Budapest.

Fiáth, A. / Kiss, T. (1994): Dicsõ múlt - a Kontrax vállalatcsoport története (Glorious past history of the Kontrax-group). Vezetéstudomány. June.

H. L. (1994): Holdinggá szervezik a Rábát (Rába will be transformed into holding). Magyar Hírlap. 6 May.

Hungenberg, H. (1992): Die Aufgaben der Zentrale (Ansatzpunkte zur zeitgemäßen Organisation der Unternehmensführung in Konzernen). Zeitschrift für Organisation. Nr. 6.

Huszty, A. (1995): A Pannonplast és a stratégia - a szellemi erõk összpontosítása (The Pannonplast-group and the strategy - concentration of the rational forces). Menedzser Piac. January.

Makai, L. (1991): Rázós úton. A társas magánvállalkozások formaválasztásának folyamatai 1982-tõl 1989-ig (On rough way. Processes of choosing organizational and legal forms for private entrepreneurships from 1982 to 1989). Vezetéstudomány. January.

Máriás, A. et al. (1981): Organization of large industrial enterprises in Hungary: a comparative analysis. Acta Oeconomica. Vol. 27. Nr. 3/4.

Matolcsy, G. (ed.) (1991): Lábadozásunk évei. A magyar privatizáció (Years of our reconvalescence. The Hungarian privatization). Privatizációs Kutatóintézet. Budapest.

Meixner, Z. (1991): Magánvállalati stratégiák (Strategies of private organizations). Figyelõ. 15 August.

Meixner, Z. (1993): A holding holdudvara (Satellits of the holding). Figyelõ. 7 December.

Móra, M. (1991): Az állami vállalatok (ál)privatizációja (Pseudo privatization of state enterprises). Közgazdasági Szemle. June.

Sárközy, T. (1986): Egy gazdasági szervezeti reform sodrában (In the drift of an organizational reform). Magvetõ Kiadó. Budapest.

Schweitzer, I. (1982): A vállalatnagyság (The company size). Közgazdasági és Jogi Könyvkiadó. Budapest.

Szalai, E. (1992): Perpetuum mobile? Nagyvállalatok az államszocializmus után (Perpetuum mobile? Large enterprises after the period of state socialism). Valóság. April. 
Tari, E. (1988): Iparvállalatok belsõ irányítási szervezete (Organizational structure of the industrial enterprises). Közgazdasági és Jogi Könyvkiadó. Budapest.

Tari, E. (1994): Stratégiai szövetség és privatizáció. A Chinoin-Sanofi „házasság” (Strategic alliance and privatization. The Chinoin-Sanofi „marriage”). Esettanulmány. BKE Vezetési és Szervezési Tanszék.

Theissen, M.R. (1991): Der Konzern. Poeschel Verlag. Stuttgart.

Új Dunkerque (1994): A Microsystem felszámolása (New Dunkerque: winding-up of Microsystem). Figyelõ. 12 December.

Varga, G. (1993): Korszakváltás a Fotex Rt-ben. (Beginning if a new era in the Fotex group). Figyelõ. 11 March.

Varga, G. (1993): Növekedési csapda (Pitfall of growth). Figyelõ. 25 March.

Voszka, É. (1991a) : Ownership reforms or privatization. Eastern European Economics. Fall.

Voszka, É. (1991b): Tulajdonosok és menedzserek. (Owners and managers). Európa Fórum. No. 2.

Voszka, É. (1994): An attempt at crisis management and failure of the spontaneous privatization. Industrial and Environmental Crisis Quarterly. Vol 8. No.1. 